\title{
Measuring the Impacts of Roads Infrastructure on Manufacturing Location
}

\author{
Yong Wan, XianglinXu" \\ School of Government, Peking University, Beijing, China \\ *Corresponding Author.
}

\begin{abstract}
Using a detailed dataset on manufacturing firms, this study analyses the link between roads infrastructure and manufacturing location in Heilongjiang province, China. The results show that the improvement in roads facilities has very limited impact on the agglomeration of economic activities in Heilongjiang province during the 2001-2013 period, but this impact has changed to be significantly positive during 2008-2013 period, which has seen greater concentration. The explanation for this finding could be that the local protectionism and failed market economy took place in Heilongjiang province more recently. We also try to differentiate this distributive effect of road infrastructures across manufacturing sectors. The empirical results show that the technology-intensive and labor-intensive firms show a greater preference for areas with better road networks, while the resource-oriented industries appear to be not attracted by better road infrastructure. Important policy implications emerge from our findings for transport planning, enabling manufacturing firms to benefit from agglomeration economies and regions to achieve sustainable economic growth.
\end{abstract}

Keywords: Road infrastructure, manufacturing agglomeration, firm location, transport planning, Heilongjiang province

\section{Introduction}

The uneven spatial distribution of manufacturing firms is an important issue for academic research and political decision making. Most studies focus on exploring the determinants of the distribution of firms ${ }^{[1]}$. When set up a firm , one of the most important aspect that should be taken into account is where to locate the business. The firms and entrepreneurs shouldconsider it carefully.They need to understand where to locate the business determines the success or failure of the future of company.Therefore, public administrators try to guide these decisions and increase the likelihood of success through initiatives related to land-use change, transport infrastructure, taxation and financial assistance.Transportation infrastructure is regarded as a significant factor affecting the regional manufacturing location. Classical and neoclassical location theories based on cost minimization, emphasize the impact of transportation costs, labor costs, and market demand on industrial location. The new economic geography emphasizes the role of transportation cost, market scale, and scale economy in the choice of industrial location in the incomplete competition market ${ }^{[2]}$.Many empirical studies also analyze the impact of transport infrastructure on the birth and relocation of industrial enterprises ${ }^{[3]}$. However, it is still unknown how a firm's influence on transportation facilities affects the behavior of a firm to locate a site in a geographical area ${ }^{[4]}$.

Transport infrastructures have greatly contributed to China's growth miracle in the post-reform period ${ }^{[5]}$. Especially in the eastern region, transport investment facilitated industrial concentration in these provinces, and had a significant impact on the emergence of the coastal economic belt ${ }^{[6]}$. Differing from the previous studies, in this paper we concentrate on the distributive effect of transport infrastructure in a northeastern province of China, Heilongjiang province. Heilongjiang province is an interesting case.Historically, Heilongjiang province took a lead in the industrial development of China from 1949 to the 1990s. However, Asa main part of the Northeast Region,Heilongjiang province has lagged far behind the coastal provinces since the 1990s, especially in recent years. Some research pointed out that the backward industrial structure and poor manufacturing distribution seemed to be one of the key factors for the low growth in the last decade ${ }^{[7]}$. However no empirical findings could be found from

ISSN: 0010-8189

(C) CONVERTER 2021

www.converter-magazine.info 
previous studies. Whether transport investment in Heilongjiang province has helped local manufacturing agglomeration as in better developed coastal provinces becomes a very important issue for the provincial decision makers. Thus, we propose this study to investigate the influence of transport infrastructure on manufacturing location in Heilongjiang province.

The paper contributes to the existing literature on manufacturing location and transport infrastructure impacts in the following ways. In this study, we address the distribution of transport infrastructure using micro-level firm data instead of macro data. Geographically detailed studies can reveal spatial distributive patterns, while these tend to be lost at the aggregated scale ${ }^{[8]}$. Besides that, as part of our exploration, we attempt to explore the various distributive effects of transport facilities among different manufacturing sectors. The findings of this investigation could have important implications for decision making on transport planning with the purpose of proper distribution of industries by local governments. Thirdly, we provide a case study of backward province of China, which is a valuable supplement to the existing studies focusing on the developed coastal areas.

The article begins with a theoretical presentation of transport and industrial location in Section 2. Section 3 provides an overview of the development of road infrastructure construction and the distribution of industries in Heilongjiang province. The empirical study on the impact of roads facilities on manufacturing location is reported in Section 4 . We offer our conclusions and policy implications in the final section.

\section{II.Transport Infrastructure, Economic Agglomeration and Manufacturing Location}

The research of transport has a long tradition in location theory. classical Weberian model believed,location patterns are determined by transport and factor costs ${ }^{[9]}$. The scholars of location economics have continuously expanded Weber's model ${ }^{[10]}$. Generally speaking, transportation costs areessential to location theory in its entirety, forthey differentiate space and enable its treatment in economic terms. They are,moreover, comprised in the concept of agglomeration economies as the costs ofinteraction and distance: if transportation costs were nil, there would be no reason toconcentrate activities, because doing so would not produce 'economies'. In this sense,agglomeration economies are 'proximity economies'; they are, that is to say,advantages that arise from the interaction among economic activities made possible by the lower amount of spatial friction in concentrated locations. Then, new economic geography (NEG) models again emphasize the importance of transport costs along with imperfect competition, market size and economies of scale in explaining the location of industry ${ }^{[11]}$.

From the empirical perspective, scholars investigated the relationship between manufacturing agglomeration and transport facilities, using the center periphery model, spatial analysis and regression model ${ }^{[12.13]}$. For these empirical studies, the central hypothesis is that transport network improvements affect the regional spatial distribution of firms. Someempirical findings indicate that transport facilities have a significantlypositive impact (net result) on the manufacturing location, and the improvement of transportation conditions will promote the industry to be concentrated in the region. Much of the evidence for the existence of such a distributive effect has been obtained from developed countries in recent years, such as Spain ${ }^{[14.15]}$, Portuga ${ }^{[16.17]}$, The Netherlandsand the US ${ }^{[18-21]}$. In addition, Obregon and Junyent ${ }^{[19]}$ believe that highway infrastructure is a key factor for the economic development and organization of a region, and investment in highway infrastructure is conducive to changing the industrial structure of the region and improving the mobility of people and goods.Obregon ${ }^{[14]}$ pointed out that when the inherent conditions of cities and regions are good and their willingness to attract investment projects is high, the inductive ability or development possibility provided by highway infrastructure is also high. In summary, this paper finds that the evidence from China is very limited. Previous studies have examined the distribution effects of transport from a national perspective, with fewer case studies using geographically detailed data, but more significant for transport planning decisions.

ISSN: 0010-8189

(C) CONVERTER 2021

www.converter-magazine.info 
Heilongjiang province locates in the northernmost part of China, which is adjacent to Russia, with abundant forestry resources, coal resources and petroleum resources. In the foundation years, the industry development in Heilongjiang province occupied a leading position in the state industrial economy. However, the Heilongjiang's economic development has undergone the serious problems along-with the collapse of Northeast China since 1990s. Heilongjiang province has witnessed over exploitation and utilization of resources, environmental pollution and deforestation, making its resource rich economy advantage gradually entered a recession. Since then, Heilongjiang province's backwardness status has not changed. In the year of 2013, Heilongjiang's economic output value in the past five years accounted for less than $2.5 \%$ of the national GDP, however the contribution rate is $10 \%$ in Guangdong province (these two provinces had similar contribution rate in the year of 1952.

\subsection{Manufacturing industry development and its distribution in Heilongjiang province}

As a resource rich province, the resourced-oriented industries played an essential role in Heilongjiang's economy. As presented in Table 1, in Heilongjiang Province, agricultural and sideline food processing industry output value ranked first with the proportion of $30.99 \%$, petroleum processing, coking and nuclear fuel processing industry second with $15.89 \%$, plastics industry with $5.57 \%$, food manufacturing industry fourth with $5.60 \%$, chemical raw materials and chemical products manufacturing industry fifth with $5.53 \%$. The total output value of the top three manufacturing industries accounted for over $50 \%$ of that of the whole manufacturing industry, which indicated the single structure of manufacturing industry of Heilongjiang Province with agricultural and sideline food processing industry and petroleum processing industry as main industries, both of which are classified as resource intensive industry.

Table 1 The ratio of output value of manufacturing sectors in that of the whole industry

\begin{tabular}{|c|c|c|c|c|}
\hline Ranking No. & Industries & $\begin{array}{l}\text { Output value } \\
\text { (million yuan) }\end{array}$ & $\begin{array}{c}\text { Ratio in the } \\
\text { whole } \\
\text { manufacturing } \\
\text { industry }(\%)\end{array}$ & $\begin{array}{l}\text { Accumulated } \\
\text { ratio }(\%)\end{array}$ \\
\hline 1 & $\begin{array}{l}\text { agricultural and sideline food } \\
\text { processing industry }\end{array}$ & 283.11 & 30.99 & 30.99 \\
\hline 2 & $\begin{array}{l}\text { petroleum processing, coking } \\
\text { and nuclear fuel processing } \\
\text { industry }\end{array}$ & 145.20 & 15.89 & 46.89 \\
\hline 3 & plastics industry & 52.49 & 5.75 & 52.63 \\
\hline 4 & food manufacturing industry & 51.13 & 5.60 & 58.23 \\
\hline 5 & $\begin{array}{c}\text { chemical raw materials and } \\
\text { chemical products } \\
\text { manufacturing industry }\end{array}$ & 50.48 & 5.53 & 63.76 \\
\hline 6 & $\begin{array}{c}\text { wood processing and wood, } \\
\text { bamboo, rattan, palm and straw } \\
\text { manufacturing } \\
\text { industry }\end{array}$ & 42.24 & 4.62 & 68.38 \\
\hline 7 & $\begin{array}{c}\text { pharmaceutical manufacturing } \\
\text { industry }\end{array}$ & 41.33 & 4.52 & 72.90 \\
\hline 8 & $\begin{array}{c}\text { general equipment } \\
\text { manufacturing industry }\end{array}$ & 36.56 & 4.00 & 76.91 \\
\hline 9 & $\begin{array}{l}\text { non-metallic mineral products } \\
\text { industry }\end{array}$ & 32.18 & 3.52 & 80.34 \\
\hline 10 & metal products industry & 31.40 & 3.44 & 83.87 \\
\hline
\end{tabular}

ISSN: 0010-8189 
Note: The output value of each sub-sector was at the price of 2013.

Figure 1 maps the distribution of manufacturing enterprises locating in Heilongjiang province in the year of 2013. During the observation period, the cities whose industries were at a high density of firms were Harbin, Daqing, Hegang and Qiqihar. We may tell some reasons about this distribution considering local actual natural condition. Harbin is the provincial capital of Heilongjiang, enjoying the political biased policies and initial comparable advantage. Daqing, a resource-based city with petroleum and petrochemical industry as its pillar industries because of its rich oil, was a representative of capital-intensive cities with integrated petroleum production and sale industry. Hegang and Qiqihar enjoyed a high level of specialization in agricultural and sideline product industry. The reason was that its location on the joint of Heilongjiang River and Songhua River made the area the hinterland and main grain production area of Sanjiang plain as well as grain production base of Heilongjiang Province. However, more should be known about the determinants of the location choice for manufacturing firms in this less developed region.

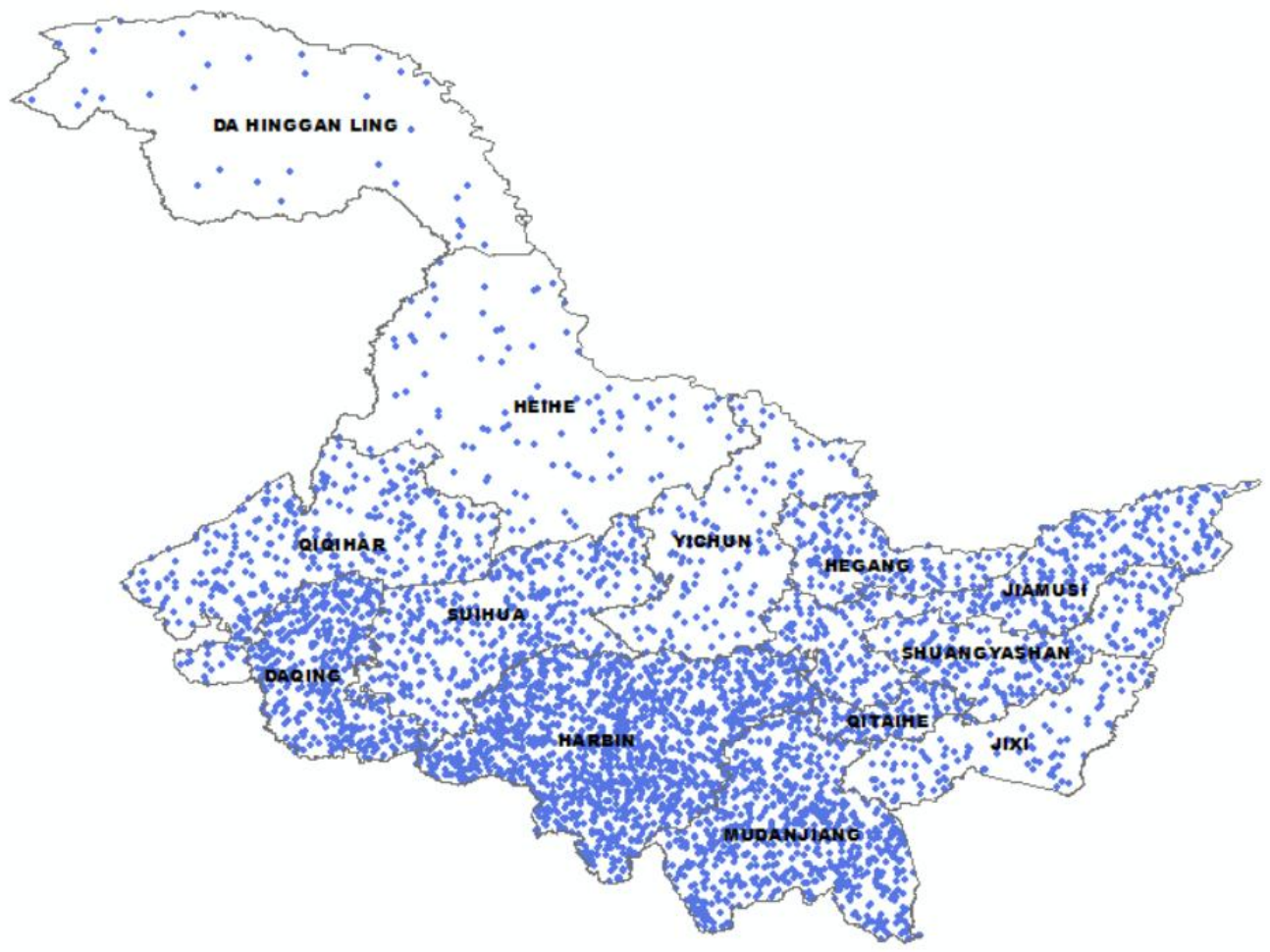

Figure 1 Spatial distribution of manufacturing firms in Heilongjiang Province

3.2 Development history and spatial distribution of roads infrastructure in Heilongjiang Province

Shenyang-Dalian Expressway, built from 1984 to 1990, is the first expressway in Northeast China, while Harbin-DaqingHighway is the first one in Heilongjiang Province with the total length of 132.8 kilometers from Harbin to Daqing. Since 2000s, with China's bandwagon of infrastructure construction, Heilongjiang province has witnessed a fast transport infrastructure development. By the end of 2014, highway in Heilongjiang province had reached 162,464 kilometers and the highway network density reached 35.864 (per hundred square kilometers). The quality of roads infrastructure in Heilongjiang province also improved to a certain level. The total mileage of expressways has reached 4084 kilometers, including Harbin-Daqing Expressway, Hegang-Jiamusi Expressway, Harbin-Mudanjiang Expressway, Mudanjiang-Suihua Expressway etc. The highway network of Heilongjiang Province continues to expand and basically forming an expressway-based transportation network, even though the lane-mile additions of road infrastructure in Heilongjiang province are less dramatic compared to those in the coastal provinces. Considering its spatial distribution of highways in Heilongjiang province, most high level highways locate in the southern part, around Harbin, adjacent to Jilin province, as Figure 2 shown. Surprisingly, the cross-state

ISSN: 0010-8189 
highway has a very limited development even though it seems to be a good chance for Heilongjiang to connect with Russian cities.

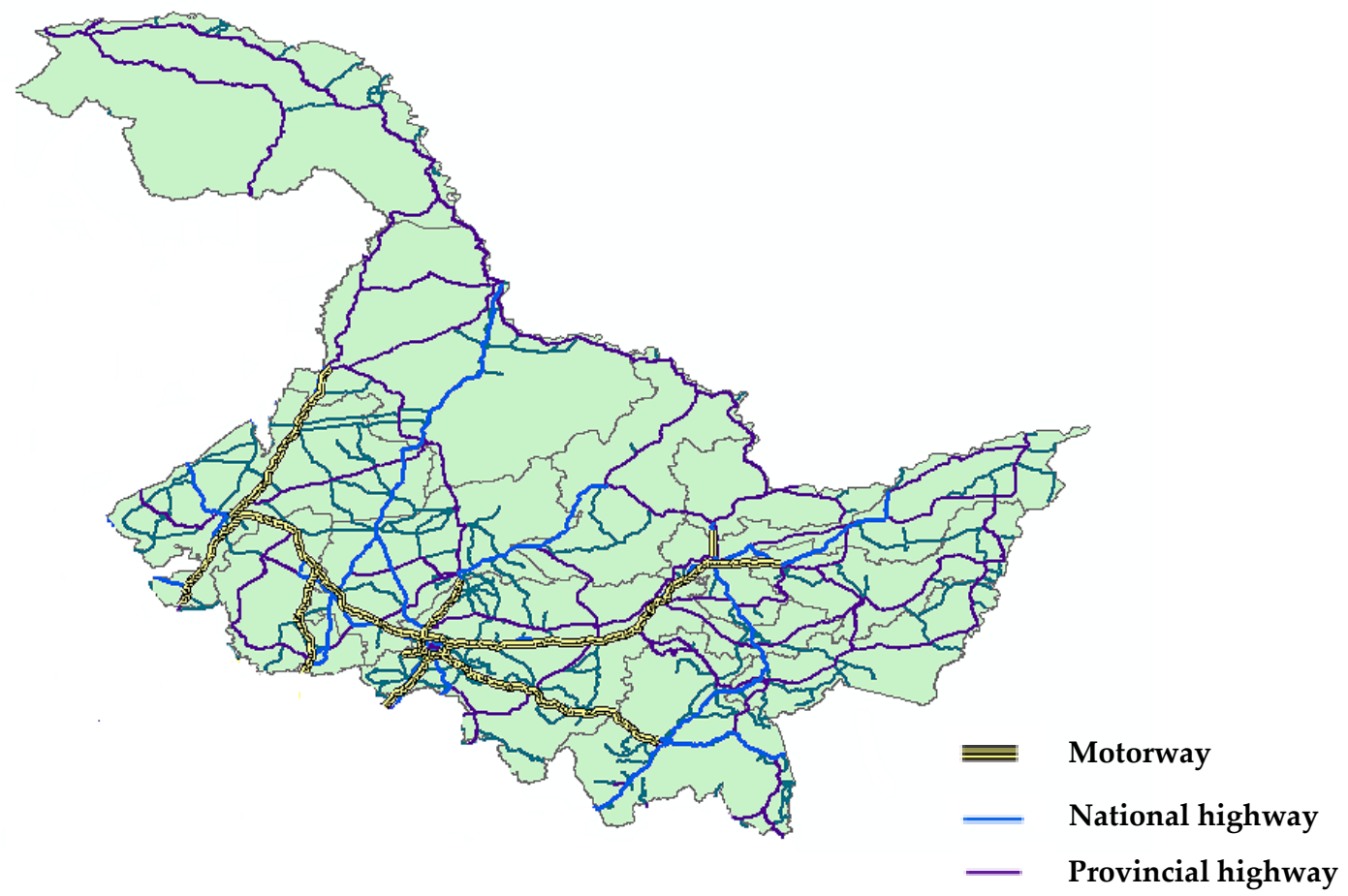

Figure 2 Roads network in Heilongjiang Province in 2013

To summarize, with national booming economy and stimulating policies, roads transport infrastructure in Heilongjiang province has seen a fast development during the post-reform periods. However, compared to the coastal regions, highway density in Heilongjiang province is relatively low, even much lower than the average level in national highway development ${ }^{[22]}$. The highway network has not fully shaped up yet and inter-provincial expressway construction saw limited progress. Actually, the status of the Northeastern highway network kept declining, even after the Northeast Area Revitalization Plan. Highway mileage in Northeast China accounted for $23.8 \%$ of the national highway mileage in 1995 , but fell to $7.8 \%$ in 2014 . The decline in transportation status in Northeast China may to some extent influence the change in economic status. As a main part of Northeast China, Heilongjiang province has lagged behind other provinces both in its economic performance and transport construction as well.

Moreover, comparing Figure 1 with Figure 2, it seems that most manufacturing firms chose to locate around the motorways. The spatial distribution of manufacturing activities and road infrastructure co-evolve in Heilongjiang province. However, we still can't tell the exact role of roads facilities on shaping industrial distribution pattern for this case. Thus, empirical investigation will be unfolded in the next section.

\section{Iv.An Empirical Examination of Agglomeration Impacts of Roads Facilities in Heilongjiang Province}

As explained above, the main objective of this paper is to analyse the influence of roads infrastructure on location decisions of manufacturing firms for the case of Heilongjiang province. The results from this study are expected to explore how the firms agglomeration change with the roads improvement and how access to roads infrastructure can produce very different results depending on sectors. 
4.1 Variables selection and formulation of models

In this study we describe the spatial development pattern of firms distribution by location quotient $(L Q)$, which is a way of quantifying concentrated industries or clusters in an area compared with the national pattern (average). The $L Q$ measures the level of industrial agglomeration in region i $\left.L Q_{i}=\frac{I Y_{i} / Y_{i}}{I Y / Y}\right)$. Here IY is the industrial output value and $\mathrm{Y}$ indexes the total GDP in the whole region. Besides transport infrastructure, we also consider the market capacity $(M A R)$, localization economies $(L O C)$, the level of opening-up (OPEN), government intervene $(G O V)$ and the level of economic development $(E C O)$ as the determinants for the manufacturing location decision based on the models of regional economics and new geography economics.

\section{$\mathrm{LQ}=\mathrm{f}(\mathrm{ROAD}, \mathrm{MAR}, \mathrm{LOC}, \mathrm{OPEN}, \mathrm{GOV}, \mathrm{ECO})$}

Since roads infrastructure has a typical network characteristic, in order to fully consider the spatial factors, we develop the empirical model in a spatial context. We added a spillover variable of motorway network ( $W * \operatorname{Road}$ ), in order to control for the effects of this key factor on spatial concentration of industries driven by transport improvement in surrounding units. A binary contiguity matrix is used to construct the spatial weighted matrix which assumes only contiguous cites can influence each other.

Thus the following estimation model on the panel data could be constructed:

$$
\begin{aligned}
& L Q_{i t}=\kappa_{i}+\lambda_{t}+\gamma_{1 i} R O A D_{i t}+\gamma_{2 i} M A R_{i t}+\gamma_{3 i} L O C_{i t}+\gamma_{4 i} O P E N_{i t} \\
& +\gamma_{5 i} G O V_{i t}+\gamma_{6 i} E C O_{i t}+\gamma_{7 i} W_{i j} R O A D_{i t}+\varepsilon_{i t}
\end{aligned}
$$

Where sub-index $\mathrm{i}(\mathrm{j})$ indicates a particular prefecture $(i \doteq j)$, and $w_{i j}$ comes from the weighting matrix $\mathrm{W}$ describing the "neighborhood" of prefectures. In particular, we use binary contiguity matrix, where all entries for prefectures sharing common borders are set to be equal to " 1 ", and all other entries are " 0 ". $k_{i}$ is municipality specific parameter considering unmeasured characteristics of municipalities, $\lambda_{t}$ is year specific parameter, which controls for temporary shocks or policy changes that might have affected all municipalities at the same time and $\varepsilon_{i t}$ is the stochastic error. Aiming at the possible omitted variables, simultaneous causality between agglomeration and transport infrastructure or other economic variables and endogenous problems caused by measurement errors in models, all the models in this paper adopt the method proposed by Arellano and Bond ${ }^{[11]}$ and the first-order lag of each variable is estimated as a tool variable. Now that the econometric method and its specification seem clear, we need to find the variables to quantify all the factors.

\subsection{Data collection}

The location quotient of manufacturing industry serves as the dependent variable in this study. The level of firms agglomeration measured by the location quotient can be classified into two aspects in this paper: firstly, the location quotient of manufacturing industry to measure the manufacturing industry gathering in each city; secondly,the location quotient ofmanufacturing firms in sub-sectors to measure the sub-sector manufacturing gathering. In addition, the main business revenue is utilized in the paper as the measurement index to ensure the continuity and consistency of the data. The key independent variable of this study is the transport facilities, which we adopt the roads density in each city as the proxy.

Regarding thecontrolling variables, the paper adopts per capita GDP to measure the local market capacity, the level of opening-up represents the degree of economic openness, measured by proportion of the total import and export output in GDP. Localization economies occurs when industries in the same sector gather in a particular region to gain

ISSN: 0010-8189 
mutual economic benefits though their correlation. The proportion of industrial added value in GDP is decided to be the indicator of the level of localization economy in a region. Moreover, the proportion of government expenditure in GDP is utilized as an index to measure the level of government intervention. The proportion of fixed assets in total investment is introduced in the paper to reflect the economic development of a city.

All data this study used are from multiple sources, including China Industrial Enterprise Yearbook, China Regional Economic Statistical Yearbooks and the China City Statistical Yearbook from 2001 to 2011. Complementary data was obtained from the Heilongjiang Province Statistical Yearbooks from 2001 to 2006.Geographic measures were constructed using ArcGIS software based on the basic map data from the National Fundamental Geographic Information System of China.

\subsection{Resultsand discussion}

\subsubsection{The results of specifications}

Table 2presents the estimation results for Equation 2 for the whole observation period and two sub-periods. As the first column of Table 2 indicates, government intervention was in negative correlation to the manufacturing gathering, while the market capacity and economic development level were in positive correlation with agglomeration. Clearly, the government intervention happened in Heilongjiang province has hindered industrial agglomeration. Firms are located according to the government instructions instead of market rules. The decreasing transportation can not change the relocation choice because of the government intervention.

Table 2 Specifications for whole observation period and sub-periods

\begin{tabular}{llll}
\hline & $2001-2013$ & $2001-2007$ & $2008-2013$ \\
\hline Road infrastructure (ROAD) & $0.262(-0.747)$ & $0.633(-1.305)$ & $0.950(-0.301)^{* * *}$ \\
\hline Localization economies (LOC) & $-4.025(-1.714)^{* *}$ & $-9.929(-3.752)^{* * *}$ & $0.442(-0.376)$ \\
\hline Market capacity (MAR) & $0.36(-0.375)^{*}$ & $0.914(-0.762)^{* *}$ & $0.0507(-0.078)^{* *}$ \\
\hline Level of opening-up (OPEN) & $-0.445(-0.565)$ & $0.0326(-0.92)$ & $-0.165(-0.167)$ \\
\hline Government intervene (GOV) & $-2.517(-2.776)^{* *}$ & $-9.218(-10.39)^{*}$ & $-1.145(-0.505)^{* *}$ \\
\hline Economic development (ECO) & $0.681(-1.137)^{* *}$ & $4.277(-3.428)^{*}$ & $1.050(-0.245)^{* * *}$ \\
\hline Spillover of roads (WROAD) & & & \\
\hline Constant & $2.732(-0.643)^{* * *}$ & $5.704(-1.963)^{* * *}$ & $0.177(-0.244)$ \\
\hline Observations & 169 & 91 & 78 \\
\hline R-squared & 0.263 & 0.148 & 0.437
\end{tabular}

Note: The standard deviation is in the bracket. Significant coefficient are indicated by *,**,*** for significance at the $1 \%, 5 \%$ and $10 \%$ levels respectively.

Differing from the findings of most previous studies, our regression result in the paper shows the positive but not significant coefficient of roads infrastructure, indicating that, there is little relation between roads infrastructure improvement and the growth in manufacturing industry gathering in Heilongjiang province during the whole observation period. However, when we run the regression for the two sub-periods, the insignificant coefficient for the 2001-2007 period changes to be statistically significant for the period of 2008-2013. That is to say, more and more manufacturing enterprises in the Heilongjiang province gathered in a certain area with better accessibility in recent years. The possible reasons for the ambiguous effect of roads improvement on manufacturing concentration in Heilongjiang province are as follows.

Theoretically speaking, investment into road infrastructure might favour internal transport, which may lead to redistribution of firms ${ }^{[18]}$. But this argument seems short-sighted, because even in the capitalism story, local governmentswould love local companies to export to other locations. After all, transport is a two-wayprocess.In 
order to ensure continued economic growth and fiscal revenue stability of the region, governments at all levels exerts the protection policy for local enterprises, but erects trade and administration barriers for foreign ones and their products to keep the competitive advantage of local enterprises. In Heilongjiang Province, theregional protectionism is serious even in the post-reform periods, so external goods are inaccessible to the local market, which may weaken the upgrading ability of local goods here. In addition,since inner provincial cities are similar in terms of resources, the repetitive exploitation and processing of the same resource led to the similar industrial chain in different cities, which led to repetitive construction of industry bases and waste of resource within province(for example, Daqing and Da Hinggan Ling Prefecture were rich in petroleum; Jixi, Hegang, Shuangyashan, and Qitaihe were rich in coal). Hence, the economic policy of protectionism in the province resulted in its industrial slowdown and economic stagnation.In the later 2000s, with the weakening of regional protectionismand the mitigating of trade barriers (because of the state policies), goods can be freely circulated in the region to a certain extent. Firms could choose their own location through market rules (the trade-off between transportation cost and agglomeration benefits). With the decreasing transportation cost, more and more enterprises choose to concentrate together in order to get the agglomerative benefits, which explained why the highway had a great influence on the gathering of manufacturing industry in Heilongjiang province after 2008.

\subsubsection{Regression results of industrial sectors}

According to regression results in Table 2, the highway improvement in Heilongjiang province had a significant influence on manufacturing concentration after 2008. In order to differentiate the influence across sectors, our study also analyzes the impact of roads infrastructure on manufacturing gathering in sub-sectors from 2008 to 2013, and moreover, discusses the influence mechanism of highway on these sub-sector agglomeration. We run the regression for all national industrial sectors (a total number of 43 sectors). Focusing on our research purpose, Table 3 just provides the results for the sectors in which the significantly positive effect of road infrastructure could be captured.

Table 3 Results of regression from the perspective of industry

\begin{tabular}{|c|c|c|c|c|c|c|c|c|}
\hline Variables & ROAD & LOC & MAR & OPEN & GOV & ECO & Constant & $\begin{array}{l}\text { R-squar } \\
\text { ed }\end{array}$ \\
\hline $\begin{array}{c}\text { Food } \\
\text { manufacturing }\end{array}$ & $2.527^{* * *}$ & $-3.061 * *$ & 0.00982 & 0.966 & 1.507 & $-1.943^{* *}$ & $2.070^{* *}$ & 0.302 \\
\hline Textile & $5.759 * * *$ & $-5.269 * * *$ & 0.0236 & 1.254 & -1.356 & -1.873 & $2.509^{* *}$ & 0.402 \\
\hline Closing & $1.312^{* *}$ & -0.700 & $\begin{array}{l}0.878^{* *} \\
*\end{array}$ & 0.215 & -0.247 & -0.185 & -0.412 & 0.579 \\
\hline $\begin{array}{c}\text { Paper and } \\
\text { printing }\end{array}$ & $1.521 * * *$ & $-3.012 * * *$ & $\begin{array}{l}0.429 * * \\
*\end{array}$ & -0.121 & $-1.982 * *$ & $\begin{array}{l}1.189 * * \\
*\end{array}$ & 0.402 & 0.431 \\
\hline $\begin{array}{l}\text { Chemical } \\
\text { products }\end{array}$ & $2.336 * * *$ & $0.996 *$ & $0.229 *$ & $0.680 * *$ & -0.617 & -0.00587 & -0.477 & 0.512 \\
\hline $\begin{array}{l}\text { Medicina } \\
\text { products }\end{array}$ & $1.459^{* *}$ & $-2.319 * *$ & 0.135 & -0.534 & -1.500 & 0.557 & $0.987 *$ & 0.212 \\
\hline $\begin{array}{l}\text { Chemical fiber } \\
\text { manufacturing }\end{array}$ & $3.009 * * *$ & $-4.008 * * *$ & $0.555^{*}$ & -0.406 & -0.686 & 0.988 & 0.172 & 0.225 \\
\hline Plastic products & $2.562 * * *$ & -0.424 & 0.282 & $\begin{array}{l}1.945^{* *} \\
*\end{array}$ & 1.780 & 0.600 & $-1.074 *$ & 0.366 \\
\hline Metal products & $1.631 * * *$ & $-1.589 * * *$ & $\begin{array}{l}0.453 * * \\
*\end{array}$ & $0.542 * *$ & -0.889 & $0.714 * *$ & -0.115 & 0.471 \\
\hline $\begin{array}{c}\text { General } \\
\text { equipment } \\
\text { manufacturing }\end{array}$ & $2.612 * * *$ & -0.844 & 0.0724 & 0.197 & -0.586 & 0.976 ** & -0.465 & 0.328 \\
\hline $\begin{array}{c}\text { Special } \\
\text { equipment } \\
\text { manufacturing }\end{array}$ & $3.798 * * *$ & 0.759 & -0.339 & 0.781 & 0.607 & -1.252 & 0.152 & 0.211 \\
\hline
\end{tabular}

ISSN: 0010-8189

(C) CONVERTER 2021

www.converter-magazine.info 


\section{Transportation} equipment manufacturing

Instrumentation

and culture, office machinery manufacturing

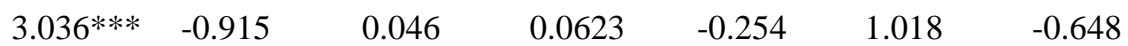

0.347

According to the result displayed in the Table 3, there were 13 sub-sectors of manufacturing industry strongly influenced by the highway density, of which five belonged to the labor-intensive manufacturing industry, four belonged to the capital-intensive manufacturing and four belonged to technology-intensive. Clearly, there is considerable inter-industry variation in the effects of roads infrastructure on manufacturing concentration. Most technology intensive and labor intensive industries show a specific preference for locations with higher accessibility. For instance, road infrastructure improvement was in positive correlation to the gathering of chemical raw material and chemical product manufacturing industry, medical product manufacturing industry, and chemical fiber manufacturing industry. All of these industries belonged to the technology-intensive industry ( with a total number of six sectors in the national sector classification), and were greatly influenced by highway change. This finding is reasonable since the technology intensive manufacturing firms reply more on talent and technology, and have less reliance on resources. These firms have more autonomy for the choice of production factors including where to locates, which is easier to realize the free flow of labor, talents and other elements. Therefore it's not difficult to understand we found that the technology intensive firms show a clear preference for the better road infrastructure.

In addition, it also had a big influence on the gathering of food manufacturing industry, textile and clothing manufacturing industry, plastic product manufacturing industry, and printing and recording media industry, all of which were the labor-intensive industry. The reason is with enormous front-line workers demanded in the large-scale production and processing manufacturing, these industries had to ensure a relatively labor cost, which was the foundation and condition for their production and operation, so they needed to be located close to the market, people, and highway in order to achieve development. Accordingly, more and more industries of this type gathered as the highway density increased. Moreover, food due to its short shelf-life needed to sell in a short time, imposing demanding requirement for speed on transportation; processed textile and clothing products needed to be delivered to other regions in a large batch, so these industries deeply influenced by the infrastructure of highway were located at the area of the dense highway network, of which the guideline to set up factories was labor-oriented one.

However, the better transport facilities have less attractive for the resource-oriented firms location. In other words, the resource-oriented industrial sectors were not affected by the roads distribution, which could be explained with two points. First, the oil and coal industries were controlled by government rather than market. The reason is that these industries in Heilongjiang province where oil and coal resources were rich were heavily dependent on the external market as their output grew slowly while in high demand in China due to the non-renewability of oil and coal. Moreover, technology and security concerns in the exploration led to government's domination over these two industries. Second, reclamation area's operation mode with Heilongjiang province's characteristics freed the gathering of agriculture and sideline food processing industry from the influence of highway density. Located on the southern foot of Lesser Khingan Mountains, the reclamation area of Heilongjiang province, in the charge of nine farm management bureaus, was evenly distributed on fertile Songnei Plain and Sanjiang Plain and covered most areas of the province with the acreage of 55.4 thousand square kilometers. The reclamation area, with dense and concentrated land resources with large share per capital, was under large-scale mechanized operation with a developed flood control and irrigation system, so it could provide a large amount of grain products for the country. Hence, considering the fixed location of the reclamation area with such a special operation mode where the raw material was produced, the gathering of the agriculture and sideline food processing industry whose location was raw-material oriented was designated to be less impacted by the highway density.

ISSN: 0010-8189 
Based on the information in Table 1 in the Sec. 2, the resource-oriented industry is the backbone of Heilongjiang's economy, agricultural and sideline food processing industry petroleum processing, coking and nuclear fuel processing industry account $46.89 \%$ in total production value of Helilongjiang province in the year of 2013. Thus, it can make sense that we can't find the positive effect of transport facilities on industries concentration since the pillar industry is not sensitive to the improvement of roads infrastructure.

\section{Conclusion and Policy Implications}

This research has underlined the impact of roads infrastructure on manufacturing agglomeration for the case of Heilongjiang province, China. A key finding of our study is that the improvement in roads facilities has very limited impact on the location choices of economic activities in Heilongjiang province during the 2001-2013 period, but this impact has changed to be significant during 2008-2013 period. The possible explanation for these findings could be the regional protectionism and unsuccessful market economy transition in the last decades. Another important finding is that road infrastructure has a differential impact across manufacturing sectors. The better road infrastructure appears to have facilitated technology-intensive and labor-intensive industries concentration, but show little attractiveness to the resource-oriented firms which are the pillar industries for Heilongjiang province.

The results raise some important policy implications for Heilongjiang province. First of all, the local government could reduce its intervention in policy and industries, and lower the entry threshold to expand business field for the private capital in order to fully realize the flow of production factors induced by transport improvement. The local governments are supposed to gradually remove administrative barriers between cities, make full use of accessibility of traffic to promote the free flow of production factors, thus building complementary advantages to improve the overall competitiveness of regions.Secondly, the decision-makers had better adjust their industrial structure in light of road distribution and expansion with the purpose of growth. This movement may be very important for the backward region to catch up. For the case of Heilongjiang province, it seems to be wise choice to increase the road infrastructure investment around the technology intensive and labor-intensive firms' locations. The new roads laying close to these firms may facilitate the transfer and transportation of products. Meanwhile, the transport network could lead to the agglomeration of the same type industries. The implementation of such planning is conducive to technology (labor) intensive manufacturing agglomeration, which could improve the competitiveness of the industry and optimize resource allocation. The emerging industrial cluster could come into being competitive advantage, and promote the sustainable development of regional economy.

\section{References}

[1] D.A.Aschauer,"Is Public Expenditure Productive,” Journal of Monetary Economics, vol. 23, no. 2, pp. 177-200, 1989.

[2] D.Banister,Y.Berechman, "Transport investment and the promotion of economic growth," J. Transp. Geogr, vol. 9, no. 3, pp. 209-218, 2001

[3] C. David, M. Fay, "The Effect of Infrastructure Networks on Economic Growth," Department of Economics,Columbia University, New York, 1993

[4] G.Cazzavillan, "Public Spending, Endogenous Growth and Endogenous Fluctuations Working Paper," University of Venice, 1993.

[5] P.P.Combes, M.Lafourcade, "Transport Cost Decline and Regional Inequalities:Evidence from France," CEPR Working paper, no.2894, 2002.

[6] N.Crafts, A.Mulatu, "What Explains the Location of Industry in Britain, 1871-1931," Journal of Economic Geography, vol. 5, no. 4, pp. 499-518, 2005.

[7] D. Banister, Y.Berechman, "Transport Investment and the promotion of the economic growth," Journal of Transport Geography, vol. 9, no. 3, pp. 209-218, 2001.

[8] M.Fujita,J.Thisse, "Economics of Agglomeration, Cities, Industrial Locationand Regional Growth," Cambridge University Press, London, 2002. 
[9] M.Fujita, P.Krugman, A.J.Venables, "The Spatial Economy, Cities, Regionsand International Trade," The MIT Press, Massachusetts, 1999.

[10] A.Holl, "Manufacturing location and impacts of road transport infrastructure: empirical evidence from Spain," Reg. Sci. Urban Econ, vol. 34, pp. 341-363, 2004.E.Louw, M.Leijten, E.Meijers, "Changes subsequent to infrastructure investments: forecasts, expectations and ex-post situation," Transp. Policy, vol. 29, pp. 107-117, 2013.

[12] A.Losch,"The economics of location,” New Haven:Yale University Press, 1959.

[13] A.Holl, "Start-ups and relocations: manufacturing plant location in Portugal," Pap. Reg. Sci.,vol. 83, pp. 649-668, 2004.

[14] E.Meijers, J.Hoekstra,M.Leijten,E.Louw, M.Spaans, "Connecting the periphery: distributive effects of new infrastructure,” J. Transp. Geogr, vol. 22, pp. 187-198, 2012.G.Ottaviano,"Infrastructure and economic geography: an overview of theory and evidence," 2008.S.Rosenthal, W.C.Strange,"The determinants of agglomeration," Journal of Urban Economics, vol. 50, no. 2, pp. 191-229, 2001.

[17] A.C.Teixeira, "Transport policies in light of the new economic geography: the Portuguese experience," Reg. Sci. Urban Econ,vol. 36, pp. 450-466, 2006.

[18] R.W.Vickerman, "Location, accessibility and regional development: the appraisal of trans-European networks," Transp. Policy,vol. 2, no. 4, pp. 225-234, 1996.

[19] A.Weber, "Theory of the location of industry," Chicago: Chicago University Press, 1929.

[20] S.Yilmaz, K.E.Haynes, "DincM.Geographic and Network Neighbors, Spillover Effects of Telecommunications Infra-structure," Journal of Regional Science, vol. 42, no. 2, pp. 339-360,2002.

[21] N.Yu,M.D. Jong, S.Storm, J.Mi, "The growth impact of transport infrastructure investment: a regional analysis for China (1978-2008)," Policy Soc.,vol. 31, no. 1, pp. 25-38, 2012. 